\title{
Functional interaction between E2F-4 and p130: evidence for distinct mechanisms underlying growth suppression by different retinoblastoma protein family members
}

\author{
Gino Vairo, ${ }^{1}$ David M. Livingston, ${ }^{2}$ and Doron Ginsberg \\ Dana-Farber Cancer Institute and Harvard Medical School, Boston, Massachusetts 02115 USA
}

\begin{abstract}
Little is known of the mechanisms controlling the $G_{0} / G_{1}$ transition of the cell cycle. The induction of immediate early gene expression, thought to be important for this process, suggests that the key factors controlling this transition preexist in quiescent cells. The E2F family of transcription factors likely play an important role in this process, because E2F DNA-binding activity exists in quiescent cells, and the induction of at least some immediate early genes requires intact E2F regulatory promoter sites. Here, we show that the major $G_{0}$ E2F activity of primary human $T$ cells, E2F-4, is stably bound to the p130 pocket protein in association with a DP heterodimerization partner. p130-E2F-4 binding has functional implications because p130 effectively suppressed E2F-4-mediated trans-activation, and coexpression of E2F-4 overcame p130-mediated $G_{1}$ arrest more efficiently than RB-induced $G_{1}$ blockade. Conversely, E2F-1 overrode an RB-induced $G_{1}$ block more efficiently than E2F-4. Thus, p130 and RB appear to induce cell cycle arrest via biochemically distinct mechanisms that involve different E2F family members.
\end{abstract}

[Key Words: E2F; cell cycle; transcription factor; $\mathrm{G}_{0}$; p130; RB family]

Received December 19, 1994; revised version accepted February 28, 1995.

The decision to enter into or to exit from the cell cycle can be mediated by signals from the environment and sensed by specific cell-surface receptors that subsequently initiate a complex series of signaling pathways. Some of these pathways ultimately are linked to key nuclear effectors that control the cell division system. The cell cycle regulatory machinery can be considered a focal point for the integration or convergence of the various signaling pathways mediating mitogenic and antimitogenic signals. Cell cycle effectors include cyclin-dependent kinases (cdks), their corresponding regulatory cyclin partners, a recently discovered array of cdk inhibitors, and members of the retinoblastoma family of "pocket proteins" including the retinoblastoma protein (RB), p107, and p130 (Sherr 1993; Ewen 1994; Peter and Herskowitz 1994). A complex interplay exists between these various effectors, one outcome of which is the timely transcription of genes encoding essential cell cycle progression factors.

Among the participants in this cell cycle-regulating gene activation program is the E2F family of transcription factors of which four members, E2F-1, E2F-2, E2F-3, and E2F-4 have been described so far (Helin et al. 1992;

1Present address: Walter and Eliza Hall Institute of Medical Research, Royal Melbourne Hospital, Victoria 3050, Australia.

${ }^{2}$ Corresponding author.
Kaelin et al. 1992; Shan et al. 1992; Ivey-Hoyle et al. 1993; Lees et al. 1993; Beijersbergen et al. 1994; Ginsberg et al. 1994). All of them form stable complexes with at least one specific pocket protein. Moreover, E2F recognition sequences are present in the promoters of a number of cell cycle progression genes (for review, see Nevins 1992; La Thangue 1994).

E2F-1, the first E2F species cloned (Helin et al. 1992; Kaelin et al. 1992; Shan et al. 1992), serves as a paradigm for what is known of the mechanisms involved in the regulation of E2F activity in general. It complexes with pRB and not with other known pocket proteins, and binding is primarily to underphosphorylated $R B$ (pRB) (Chellappan et al. 1991; Helin et al. 1992; Kaelin et al. 1992; Shan et al. 1992). Its ability to bind both DNA and $\mathrm{RB}$ is dependent on an association with a heterodimeric partner, DP-1 (Bandara et al. 1993; Helin et al. 1993b; Krek et al. 1993).

When bound to pRB, E2F-1 retains its DNA-binding activity but loses its transcription activation function. In this setting, it likely functions as a sequence-specific transcriptional repressor, switching off the expression of certain E2F target genes, at least some of which, when active, promote cell growth (Dalton 1992; Hamel et al. 1992; Hiebert et al. 1992; Weintraub et al. 1992; Zamanian and La Thangue 1992). In response to certain growth-promoting signals, phosphorylation of $\mathrm{pRB}$ oc- 
curs, during mid-late $\mathrm{G}_{1}$, at the hands of specific cyclin/ $\mathrm{cdk}$ complexes. This process results in the release of E2F-1 from the RB-containing complex and derepression of certain E2F-1 responsive promoters, which, in turn, activates genes needed for $G_{1}$ exit (Dalton 1992; Lam and Watson 1993; Hsiao et al. 1994). As cells progress through late $G_{1}$ early $S$ phase, E2F-1 binds stably to cyclin $A / c d k 2$, and this enzyme catalyzes phosphorylation of the DP-1 subunit also bound to E2F-1, leading to a loss of E2F-1 DNA-binding function (Dynlacht et al. 1994; Krek et al. 1994). Thus, the temporal activity of E2F-1, which could be predicted to peak at the $G_{1} / S$ phase boundary is, at least in part, a result of its sequential interactions with RB during $G_{1}$ and cyclin $A$ kinase during late $G_{1}$ and $S$ phase.

Compared with the mechanisms contributing to continuous cell proliferation, the mechanisms controlling the $\mathrm{G}_{0} / \mathrm{G}_{1}$ transition are poorly characterized. Some insight into the nature of the mechanisms involved can be gleaned from studies of genes whose expression at the $\mathrm{G}_{0} / \mathrm{G}_{1}$ transition are important for cell cycle progression. For quiescent cells, the rapid, mitogen-induced stimulation of immediate early mRNA synthesis occurs in the absence of protein synthesis and suggests that key regulatory factors pre-exist in quiescent cells (for review, see Pardee 1989). The c-myc promoter (P2) contains an E2F recognition sequence, and this site is essential for c-myc expression in response to serum (Mudryj et al. 1990) as well as for its trans-activation in response to ElA (Thalmeier et al. 1989; Hiebert et al. 1991).

Consistent with a potential role for E2F in mediating the activation of certain $G_{0}$ exit genes, E2F DNA-binding activities exist in a variety of $G_{0}$ cells (Chittenden et al. 1993; Cobrinik et al. 1993; Schwarz et al. 1993). On the other hand, E2F-1 synthesis occurs primarily in late $G_{1}$ (Kaelin et al. 1992; Slansky et al. 1993; Ginsberg et al. 1994), and E2F-1 was not detected in extracts of $\mathrm{G}_{0}$ human T lymphocytes (Chittenden et al. 1993). Furthermore, E2F-1 did not activate the c-myc promoter as efficiently as it activated other E2F site-containing elements (Li et al. 1994). When in the cell cycle E2F-2 and E2F-3 are synthesized remains undefined. However, these species, like E2F-1, predominantly associate with RB in vivo (Ivey-Hoyle et al. 1993; Lees et al. 1993); and $\mathrm{RB} / \mathrm{E} 2 \mathrm{~F}$ complexes are, at most, a minor component of $\mathrm{G}_{0}$ E2F DNA-binding activity (Chittenden et al. 1993; Cobrinik et al. 1993; Schwarz et al. 1993).

In unstimulated human $T$ cells and growth-arrested immortal murine fibroblasts, there is a single, readily detectable, E2F complex designated X (Chittenden et al. 1993; Cobrinik et al. 1993). It consists of an E2F activity bound to p130 (Cobrinik et al. 1993). The sequence of p130 is more closely related to that of pl07 than RB, with the greatest homology observed in the pocket region (Hannon et al. 1993; Li et al. 1993; Mayol et al. 1993). Unlike RB, pl30 demonstrates significant homology in its "spacer" (a region in the pocket that separates the $\mathrm{A}$ and $\mathrm{B}$ pocket subdomains and is dispensable for viral oncoprotein binding) to that of p107, which mediates p107 interactions with cyclins A and E (Ewen et al.
1992; Faha et al. 1992; Lees et al. 1992). In keeping with this observation, p130 also interacts with cyclins A and $\mathrm{E}$ ( $\mathrm{Li}$ et al. 1993). Although there is no direct evidence that $\mathrm{p} 130$ functions as a tumor suppressor, the $\mathrm{p} 130$ gene maps to a region of the genome that is frequently deleted in a variety of human tumors (Hannon et al. 1993; Li et al. 1993; Yeung et al. 1993). Therefore, one might speculate that like $\mathrm{pRB}, \mathrm{p} 130$ is also a growth-regulating protein and that its interactions with certain E2F species contribute to this function. In this report we describe results that strongly support this hypothesis and speak to a specific role of p130 complexed with E2F-4, a known oncogene (Ginsberg et al. 1994), in $G_{0} / G_{1}$ exit control.

\section{Results}

The $G_{0} X$ complex is composed of p130, E2F-4, and a $D P$ family member

Figures la and b depict the results of an electrophoretic mobility-shift assay (EMSA) analysis performed on extracts of resting $\left(\mathrm{G}_{0}\right)$ primary human $T$ cells and cycling U937 human promonocytic leukemia cells. The E2F species of both of these cell populations have been characterized previously (Shirodkar et al. 1992; Chittenden et al. 1993). Asynchronous U937 cells contain three predominant $\mathrm{E} 2 \mathrm{~F}$ complexes designated $\mathrm{A}, \mathrm{B}$ and $\mathrm{C}$ that are composed of free (unbound) E2F, RB-E2F, and p107-E2Fcyclin A/cdk2 complexes, respectively (Cao et al. 1992; Devoto et al. 1992; Shirodkar et al. 1992). In $G_{0} T$ cell extracts, a prominant E2F complex was detected (labeled $\mathrm{X}$ ) that, as described previously, migrated a bit more slowly than B (Fig. la, cf. lanes 1 and 2). The DNAbinding specificity of these various E2F complexes was confirmed in competition experiments where addition of excess, unlabeled wild-type E2F oligonucleotide, but not an equal amount of an oligonucleotide containing a mutant E2F site, abolished binding to the radioactive probe (data not shown).

Addition of a polyclonal anti-E2F-4 mouse serum (which does not recognize any of the other known E2Fssee below) resulted in an almost complete loss of $\mathrm{X}$ with a concomitant appearance of a supershifted band (Fig. la, cf. lanes 2 and 31, whereas a control mouse serum had no effect (Fig. 1a, cf. lanes 2 and 4). E2F-1 activity results from an E2F-1/DP-1 heterodimeric complex (Bandara et al. 1993; Helin et al. 1993b; Krek et al. 1993). Because E2F-4 can also heterodimerize with DP-1 in vivo (Beijersbergen et al. 1994; Ginsberg et al. 1994) and DP-1 protein is present in $G_{0}$ cells (Bandara et al. 1994), we asked whether DP-1, or a related protein, exists in X. Addition of a polyclonal anti-human DP-1 mouse serum suppressed X significantly (Fig. 1a, cf. lanes 2 and 5). A rabbit polyclonal anti-mouse DP-1 serum (Fig. 1a, lane 6) led to marked suppression of $\mathrm{X}$ and a supershift effect. The corresponding preimmune serum was inactive in this regard (Fig. la, lane 7). As described previously (Shirodkar et al. 1992; Chittenden et al. 1993), whole rabbit sera resulted in the appearance of a sharp band corresponding to a nonspecific DNA-binding activity that migrated just above $\mathrm{C}$ (Fig. 1a, lanes 6,7). 

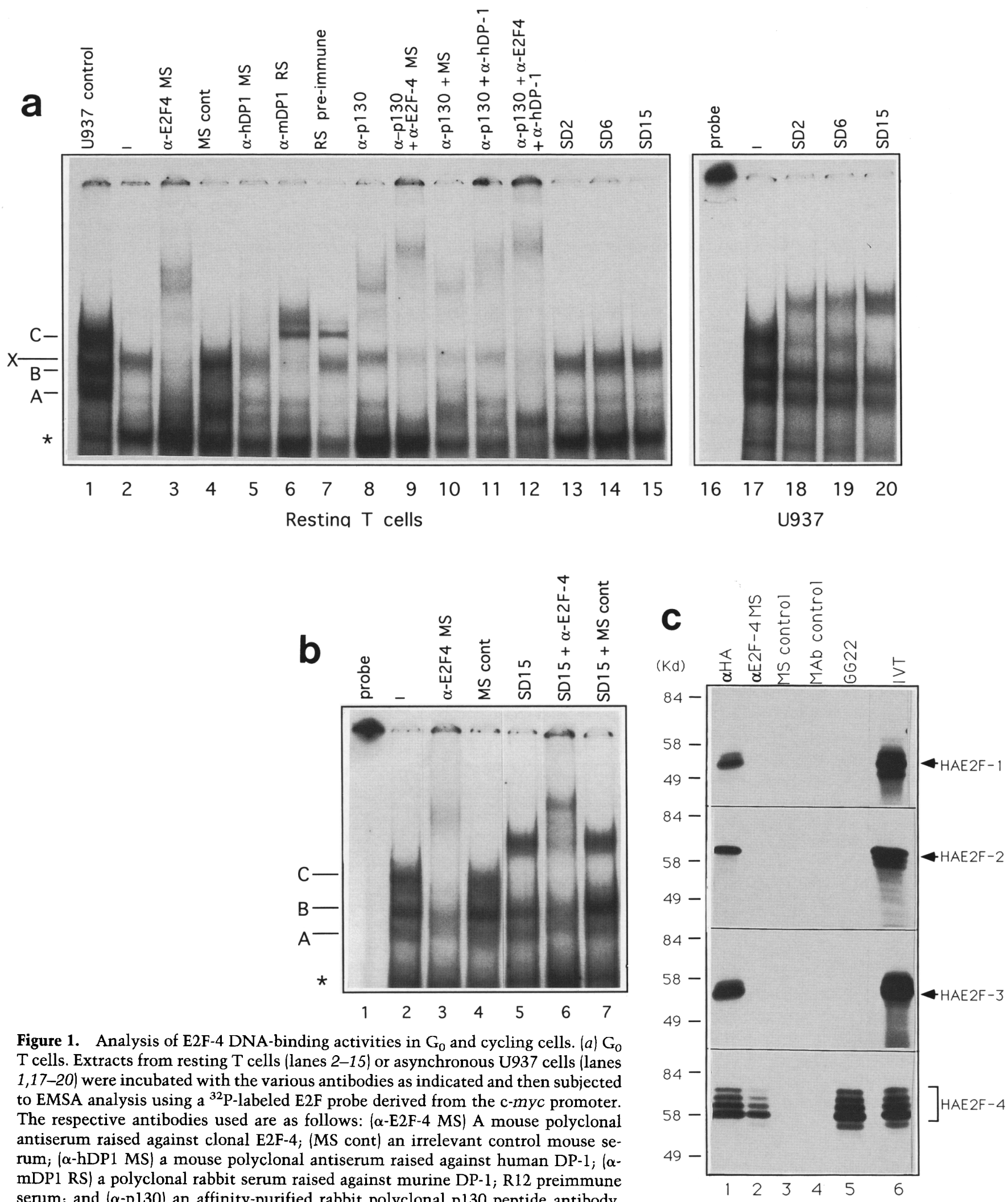

Figure 1. Analysis of E2F-4 DNA-binding activities in $\mathrm{G}_{0}$ and cycling cells. $(a) \mathrm{G}_{0}$ $T$ cells. Extracts from resting T cells (lanes 2-15) or asynchronous U937 cells (lanes 1,17-20) were incubated with the various antibodies as indicated and then subjected to EMSA analysis using a ${ }^{32} \mathrm{P}$-labeled E2F probe derived from the c-myc promoter. The respective antibodies used are as follows: ( $\alpha$-E2F-4 MS) A mouse polyclonal antiserum raised against clonal E2F-4; (MS cont) an irrelevant control mouse serum; $(\alpha$-hDP1 MS) a mouse polyclonal antiserum raised against human DP- $1 ;(\alpha-$ mDPl RS) a polyclonal rabbit serum raised against murine DP-1; R12 preimmune serum; and $(\alpha-\mathrm{pl} 30)$ an affinity-purified rabbit polyclonal p130 peptide antibody. SD2, SD6, and SD15 are p107 mAbs (Dyson et al. 1993). (X) The position of the predominant E2F complex in $G_{0} T$ cells; (A, B, C) the positions of the E2F complexes in the U937 extracts. The asterisk $\left(^{\star}\right)$ indicates a nonspecific DNA-binding activity (Shirodkar et al. 1992; Chittenden et al. 1993). (b) Cycling U937 cells. Extracts from asynchronous cultures of U937 cells were incubated with the various antibodies as indicated and then subjected to EMSA analysis as in $a$. (c) E2F-4 antibody specificity. HA-tagged E2F-1, E2F-2, E2F-3, and E2F-4 were translated in vitro and subjected to immunopreciptation with polyclonal HA peptide antibody (lane 1), polyclonal anti-E2F-4 mouse serum (lane 2), control mouse serum (lane 3), irrelevant monoclonal antibody YS140 (lane 4), and E2F-4 mAb, GG22 (lane 5). Aliquots (1 $\mu$ ) of the in vitro translation products (IVT) of the various E2Fs were analyzed directly as controls (lane 6). The resulting immunoprecipitates were analysed by SDS-gel electrophoresis. The positions of the proteins immunoprecipitated by HA antibodies are indicated at right. The gel mobilities of prestained markers and their native molecular masses (in $\mathrm{kD}$ ) are indicated at left. 
Addition of an affinity-purified anti-p130 peptide antiserum resulted in a clear supershift of $X$ (Fig. la, lane 8) as well as the appearance of a band migrating slightly slower than X itself (Fig. 1a, cf. lanes 7 and 8). In other gels electrophoresed longer than the one depicted in Figure 1 , this band was completely resolved from $X$ and because no $X$ remained, we concluded that all of $X$ was supershifted by the p130 antibody (data not shown). The nature of the band that migrated more slowly than X remains unclear, although in other experiments it did appear to bind the E2F probe specifically (data not shown). To determine whether the various protein components of $\mathrm{X}$ were present in the same complexes, combinations of antibodies were added in search of sequential supershifting effects. Addition of both p130 and E2F-4 or p130 and DP-1 antibodies, together, resulted in a further mobility shift of the supershifted p130 band (Fig. la, cf. lanes 9 and 11 , respectively, to lane 8 ), whereas control mouse serum had no such effect (Fig. 1a, lane 10). Addition of a combination of antibodies to p130, E2F-4, and DP-1 together resulted in the appearance of an even more slowly migrating species, suggesting that a triple supershift had occurred (Fig. 1a, cf. lane 12 with lanes 9 and 11 ). Consistent with a previous report (Chittenden et al. 1993), addition of three monoclonal p107 antibodies (SD2, SD6, or SD15), which recognize distinct epitopes of p107 (Dyson et al. 1993), had no effect on X (Fig. 1a, lanes 13-15), whereas they were effective in supershifting complex C from U937 cells in the same experiment (Fig. 1a, lanes 17-20). This suggests that, at a minimum, $\mathrm{X}$ contains $\mathrm{p} 130$ in the same complex with E2F-4 and a DP family member. It also is consistent with the view that X lacks pl07.

We also decided to examine the effect of E2F-4 antibody on the various E2F activities observed in extracts of cycling cells. In Figure $1 \mathrm{~b}$ it can be seen that addition of E2F-4 antibody (Fig. 1b, lane 3), but not control mouse serum (Fig. 1b, lane 4), to U937 extracts clearly (albeit not completely) supershifted complexes $A$ and $C$ and, to a lesser extent, complex B. In both the U937 cell and resting $\mathrm{T}$-cell extracts, these complexes were disrupted by a second mouse anti-E2F-4 serum (data not shown), again indicating the presence of E2F-4. The identities of these various E2F activities as free E2F, RB-E2F, and p107-E2F complexes (see above) were confirmed in independent supershift assays performed with specific antibodies to RB and p107 (for B and C, respectively, in Fig. 1) and by the ability of wild type, but not a suitable mutant, E1A-GST fusion protein, to disrupt $B$ and C, but not A (data not shown). As expected, p107 monoclonal antibody supershifted $C$ specifically (Fig. 1b, lane 5) with a subsequent further supershift of this band when both E2F-4 and p107 antibodies were added together (Fig. 1b, lane 6), but not when anti-p107 was added with control mouse serum (Fig. 1b, lane 7). These results not only confirm that in cycling U937 cells, E2F-4 is predominantly associated with p107 and, to a lesser extent with $\mathrm{RB}$, but also suggest that E2F-4 is a component of the major free E2F species (i.e., complex A). This conclusion is consistent with previous results obtained with human
T-cell extracts, demonstrating that disruption of $\mathrm{X}$ with ElA results in increased amounts of $\mathrm{A}$ /Chittenden et al. 1993).

In the above-noted experiment, a polyclonal antiserum to E2F-4 was used. Because E2F is a family of stucturally related gene products (Helin et al. 1992; Kaelin et al. 1992; Shan et al. 1992; Ivey-Hoyle et al. 1993; Lees et al. 1993; Beijersbergen et al. 1994; Ginsberg et al. 1994), we asked whether this antiserum displayed cross-reactivity with any of the hitherto cloned E2Fs. Figure 1c demonstrates that it did not immunoprecipitate in vitro-translated E2F-1, E2F-2, or E2F-3. Similarly, an E2F-4 monoclonal antibody (mAb GG22), described previously (Ginsberg et al. 1994) (which does not supershift in EMSA, data not shown/ was also specific for E2F-4 in this assay. Neither of these antibodies immunoprecipitated in vitro-translated DP-1 (a frequent component of cellular E2F complexes) (Girling et al. 1993) or E2F-5, an E2F family member identified more recenlty that is structurally more homologous to E2F-4 than the other known E2Fs (Sardet et al. 1995; data not shown). Nevertheless, we cannot exclude the possibility that these E2F-4 antibodies may recognize other, as yet unidentified, E2F species.

Interestingly, immunoprecipitation of in vitro-translated, hemagglutinin (HA)-tagged E2F-4 with the various E2F-4 antibodies, as well as with HA antibody, gave rise to a series of gel electrophoretic bands. Because the HA epitope was present on the amino terminus of E2F-4, this result depicts only products bearing an intact amino terminus. The heterogeneity of the E2F-4 banding pattern has been described previously and is most likely a result of post-translational modification of the E2F-4 polypeptide (Beijersbergen et al. 1994; Ginsberg et al. 1994; see below) and demonstrates that such modifications can arise both in reticulocyte lysates and in vivo.

\section{E2F-4 protein is present in resting $G_{O} T$ cells}

To confirm that E2F-4 exists in $\mathrm{G}_{0} \mathrm{~T}$ cells, Western blot analysis was performed with the E2F-4 mAb GG22 (Ginsberg et al. 1994). Figure 2 depicts steady-state E2F-4 levels in extracts of unstimulated human T cells, T cells stimulated with phytohemagglutinin (PHA) for $70 \mathrm{hr}$, and exponentially growing U937 cells. As mentioned previously, E2F-4 was discernible in SDS gels as a series of bands of varying mobility that most likely reflect differential phosphorylation (Beijersbergen et al. 1994; Ginsberg et al. 1994). Interestingly, although E2F-4 was readily detected in all of the samples, the relative abundance of the different forms changed after T-cell stimulation. The poststimulation pattern and that in cycling U937 cells were nearly identical (Fig. 2, cf. center and right lanes|. The $\mathrm{G}_{0} \mathrm{~T}$-cell population displayed prominent levels of the two most slowly migrating forms, whereas after stimulation, the faster migrating forms predominated. The slowest migrating band present in the stimulated T-cell preparation was absent in the U937 cell extract, possibly reflecting the presence of a greater fraction of $G_{0} / G_{1}$ cells in the $T$-cell culture (possibly 


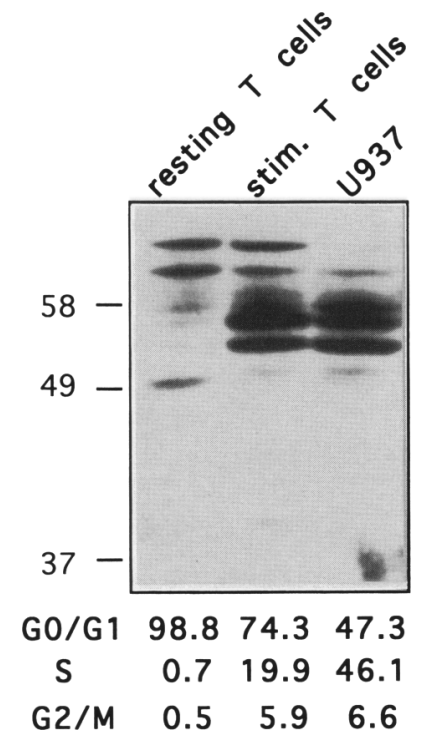

Figure 2. Steady-state E2F-4 protein levels in $\mathrm{G}_{0}$ and cycling cells. Whole-cell extracts were prepared from resting $G_{0} T$ cells, T cells stimulated with PHA for $70 \mathrm{hr}$, or asynchronous cultures of U937 cells. Steady-state E2F-4 levels were determined by Western blotting using anti-E2F-4 mAb GG22, as described in Materials and methods. The percentages of cells of the different cell populations in the various cell cycle stages are shown (bottom). The gel mobilities of prestained markers and their native molecular masses (in $\mathrm{kD}$ ) are indicated at left.

residual nonresponding $T$ cells) as shown by cell cycle analysis (Fig. 2, bottom). All extracts were prepared simultaneously, and equivalent amounts of cellular protein were analyzed in all cases. In addition, there were no detectable signs of E2F-4 proteolysis in electrophoretic mobility shift assay (EMSAs); and similar Western blotting results were obtained in multiple, independent cell extracts (data not shown). Hence, it is unlikely that the differences in E2F-4 banding pattern among the three samples tested simply reflect protein degradation during their preparation. These results suggest that there are cell cycle-specific modifications of E2F-4, possibly phosphorylation, that occur when cells exit $\mathrm{G}_{\mathrm{O}}$ and enter the cell cycle.

In vivo interaction of E2F-4 with $p 130$

in quiescent and cycling cells

We next searched for complexes of E2F-4 bound to p130 and/or p107 in quiescent and cycling cell populations by immune coprecipitation. Resting and stimulated $\mathrm{T}$ cells, as well as asynchronous U937 cells, were labeled with $\left[{ }^{35}\right.$ S]methionine and lysed, and the resulting extracts were immunoprecipitated, in parallel, with antibodies to E2F-4, p130, and p107. Equivalent amounts of radiolabeled cellular protein were assayed. After washing, the presence of pocket protein coprecipitating E2F-4 was determined by reimmunoprecipitation with the E2F-4
mAb GG22 and analyzed by SDS-gel electrophoresis (Fig. 3a). Significant quantities of E2F-4 were discernible in the p130 immunoprecipitates from both resting and stimulated $T$ cells. A less intense signal was detected in the U937 extract. E2F-4 coprecipitated with p107 in the stimulated T-cell and U937 cell extracts, with little association detected in $G_{0} T$ cells. This may reflect the lower abundance of p107 in quiescent cells (Cobrinik et al. 1993; and Fig. 3b). The band that coprecipitated with p107 from unstimulated T-cell extracts (lane 3) was a background band, because it was also observed when control monoclonal antibody was used (Fig. 3a, lane 1). In summary, these results reveal an in vivo interaction of E2F-4 and p130 in both quiescent and cycling cell populations, with a significant interaction of p107 with E2F-4 occurring only in the proliferating cells tested. In all three cell populations assayed, and in agreement with data published previously (Ginsberg et al. 1994), a weak interaction of E2F-4 with RB could be detected (data not shown). Interestingly, direct precipitation of E2F-4 resulted in the appearance of significant levels of E2F-4 in both quiescent and stimulated T-cell extracts. In contrast, little, if any, was detected in U937 cells. The reason for this difference is unclear at present.

Consistent with the results shown in Figure 2 and, as reported previously (Beijersbergen et al. 1994; Ginsberg et al. 1994), the results of Figure 3a also show that E2F-4, isolated from both $\mathrm{G}_{0}$ and cycling cell populations, migrated as a heterogeneous series of bands ranging from $\sim 57$ to $64 \mathrm{kD}$. The distribution of the E2F-4 species isolated by direct E2F-4 immunoprecipitation differed, in part, from that of the E2F-4 bound to p130 and p107. These results suggest that $\mathrm{p} 130$ and p107/Ginsberg et al. 1994) associate with a specific subset of the available E2F-4 species.

To compare the levels of labeled p130 and p107 in the immunoprecipitates from the various cell lysates analyzed above, fractions of the initial immunoprecipitates used in Figure 3a were analyzed by gel electrophoresis (Fig. 3b). p130 was readily detected in both resting and stimulated T cells, as well as in U937 cells. Notably, there were differences in the migration of p130 in the various samples. In $G_{0} T$ cells, most immunoreactive p130 migrated as a band of $\sim 126 \mathrm{kD}$. After $60 \mathrm{hr}$ of mitogenic stimulation, more slowly migrating species appeared. In asynchronous U937 cells, a single major band of $\sim 130 \mathrm{kD}$ was detected. These findings are analogous to the cell cycle-dependent changes in RB mobility that depend on its time-dependent, differential phosphorylation (Buchkovich et al. 1989; Chen et al. 1989; DeCaprio et al. 1989; Mihara et al. 1989). Consistent with this proposal and in keeping with results published previously (Cobrinik et al. 1993), we have found that the slower migrating $\mathrm{p} 130$ band can be converted to the faster species by phosphatase treatment of pl30 immunoprecipitates (data not shown). This implies that the electrophoretic heterogeneity of p130 is attributable to phosphorylation.

In contrast to p130, the levels of labeled p107 isolated in Figure 3a were low in unstimulated $\mathrm{T}$ cells and in- 

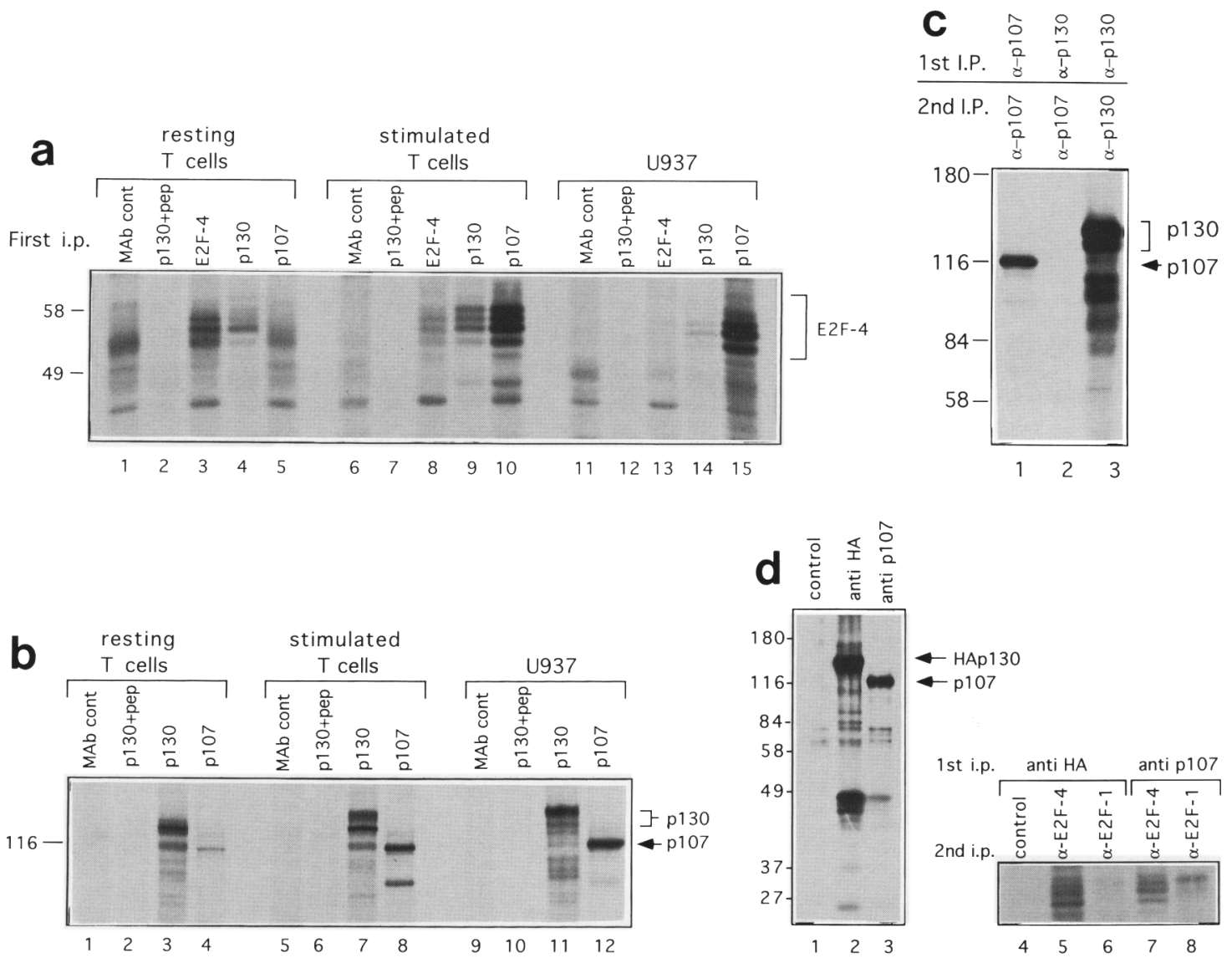

Figure 3. E2F-4 interactions with p130 and p107 in $\mathrm{G}_{0}$ and cycling cells in vivo. (a) Coprecipitation of E2F-4 with p130 and p107. Equivalent quantities of radiolabeled cellular protein from lysates of metabolically labeled resting T cells (lanes 1-5), T cells stimulated with PHA for $60 \mathrm{hr}$ (lanes 6-10), or asynchronous cultures of U937 cells (lanes 11-15) were immunoprecipitated with anti-E2F-4 mAb GG22 (lanes 3,8,13); p130 peptide antibody, C20 (lanes 4,9,14); or a mixture of the p107 mAb, SD6 and SD15 (lanes 5,10,15). After washing, the precipitates were boiled in SDS release buffer and reimmunoprecipitated with E2F-4 mAb, GG22, prior to analysis by SDS-PAGE. $(b)$ p130 and p107 in $\mathrm{G}_{0}$ and cycling cells. Fractions $(10 \%)$ of the original immunoprecipitates from $a$ were set aside after boiling in SDS release buffer and directly analyzed in parallel to monitor p130 and p107 levels in the various cell lysates. (c) Specificity of the p130 antibody. Metabolically labeled U937 lysates were

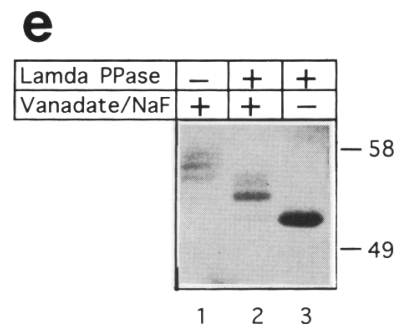
immunoprecipitated and after boiling were reimmunoprecipitated with a mixture of pl07 monoclonal antibodies (SD6 and SD15) or the C20 p130 antibody, as indicated. (d) Association of E2F-4, but not E2F-1, with overproduced p130. U2OS cells transfected with 5 $\mu \mathrm{g}$ of HAp130 (lanes 1,2,4-6) or p107 (lanes 3,7,8) expression plasmids were metabolically labeled with $\left[{ }^{35}\right.$ S]methionine, lysed, and immunoprecipitated with control mAb YS140 (lane 1), anti-HA mAb 12CA5 (lanes 2,4-6), or a mixture of p107 mAb SD9 and SD15 (lanes $3,7,8$ ). The expression levels of the introduced HAp130 or p107 were monitored by direct immunoprecipitation (lanes 1-3). Coprecipitating E2F-4 or E2F-1 was detected by reimmunoprecipitation with E2F-4 mAb GG21 (lanes 5,7) or E2F-1 mAb SQ41 (lanes 6,8). Reprecipitation with an irrelevant $\mathrm{mAb}$ YS140, was included as a control (lane 4). (e) p130 associates with phosphorylated E2F-4. C33A cells were metabolically labeled with $\left[{ }^{35}\right.$ S]methionine, lysed, and immunoprecipitated with p130 peptide antibody, C20, and reimmunoprecipitated with E2F-4 mAb GG22. The resulting immunoprecipitates were resuspended in phosphatase buffer and treated in the presence or absence of $\lambda$ phosphatase with or without the phosphatase inhibitors, vanadate and $\mathrm{NaF}$, as indicated.

creased following mitogenic stimulation. U937 cells contained more labeled p107 than stimulated T cells. Under the conditions employed, there were no detectable changes in the mobility of p107 among the various cell populations.

To exclude the possibility that coprecipitation of E2F-4 with the polyclonal p130 antibody from cycling cells was attributable to cross-reactivity with p107, we performed the experiment depicted in Figure 3c. Lysates of metabolically labeled U937 cells were immunoprecipitated with the p130 antibody. After washing, bound proteins were released and reprecipitated with a mixture of monoclonal p107 antibodies (SD6 and SD15). The results show that there was no p107 present in the p130 immunoprecipitate (lane 2), even though ample p107 and p130 were evident in this cell lysate, as detected by direct immunoprecipitation and reprecipitation with the respective antibodies (lanes 1,3). Similar results were ob- 
tained with lysates of stimulated $T$ cells (data not shown).

To further establish the specificity of the interaction of E2F-4 with p130 in cycling cells, an expression plasmid encoding p130 carrying an amino-terminal HA epitope was employed (Fig. 3d). U2OS cells transfected with expression plasmids encoding HAp 130 or untagged p107 were metabolically labeled with $\left[{ }^{35} \mathrm{~S} \mid\right.$ methionine, and the association of these exogenously introduced proteins with endogenous E2F-4 or E2F-1 was tested by coimmunoprecipitation. The results show that endogenous E2F-4 could be detected in immune complexes from cells overproducing HAp130 or p107. These complexes were precipitated with anti-HA mAb $12 \mathrm{CA} 5$ and p107 mAbs SD9 and SD15, respectively (Fig. 3d, lanes $5,7)$. Interestingly, weak coprecipitation of E2F-1 with p107 occurred in cells overproducing p107 (Fig. 3d, lane 8 ), but the analogous E2F-1/HA-p130 interaction was not evident in this experiment. These results suggest that although p107 does not bind E2F-1 under physiological conditions in vivo (Chittenden et al. 1993; Dyson et al. 1993), overproduction of p107, but not p130, can result in a detectable interaction with endogenous E2F-1.

The electrophoretic heterogeneity of the E2F-4 that coprecipitated with p130 is attributable, at least in part, to phosphorylation. Lambda phosphatase treatment of the E2F-4 coprecipitating with p130 from $\left[{ }^{35} \mathrm{~S}\right]$ Methio nine-labeled C33A cells resulted in the appearance of a single, more intense, faster migrating band of $\sim 57 \mathrm{kD}$. (Fig. 3e, lane 3), when compared with parallel samples prepared in the absence of phosphatase (Fig. 3e, lane 1), or with phosphatase in the presence of phosphatase inhibitors (Fig. 3e, lane 2).

\section{E2F-4 and a DP family member are substrates of p130-associated kinases in vitro}

p130/E2F complexes have been demonstrated, in vivo, to interact with cyclins and their associated kinases (Cobrinik et al. 1993; Li et al. 1993). Therefore, we tested whether E2F-4 may be phosphorylated by p130-associated kinases. To address this, in vitro kinase assays were performed on p130 or p107 immunoprecipitates derived from lysates prepared from resting and mitogen-stimulated T cells. In these tests any resulting E2F-4 phosphorylation was measured after this target protein was reprecipitated by E2F-4 monoclonal antibody (Fig. 4). The results indicate that similarly migrating species of phosphorylated E2F-4 could be detected in both the p130 and p107 complexes from stimulated, but not resting, $T$ cells. That similar levels of p130 were immunoprecipitated from both of these resting and stimulated populations was assured by immunoprecipitating lysates of cultures metabolically labeled in parallel with $\left[{ }^{35} S\right]$ methionine (data not shown). The phosphorylation of E2F-4 was catalyzed by kinases specifically bound to p130 or p107, because phosphorylated E2F-4 was not detected when the p130 antibody was preblocked with antigenic peptide or when an irrelevant monoclonal antibody was used (Fig. 4, lanes 6,9). Because we found that a DP-related

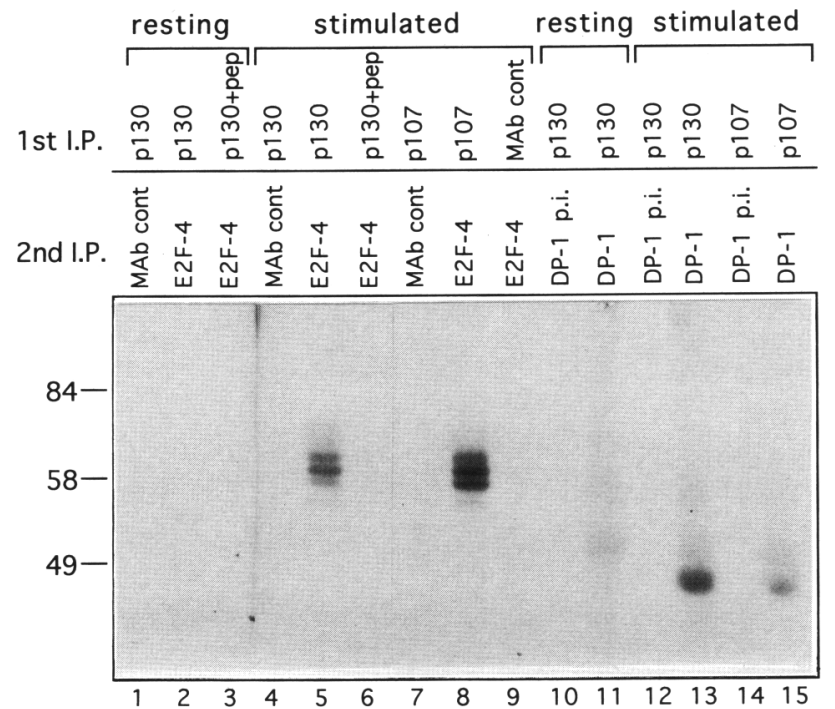

Figure 4. E2F-4 and a DP family member are substrates for p130- and p107-associated kinases in vitro. Equivalent amounts of total cellular protein from lysates of resting $\mathrm{T}$ cells or $\mathrm{T}$ cells stimulated with PHA for $\sim 60 \mathrm{hr}$ were subjected to immunoprecipitation with p130 peptide antibody, C20 (p130), or a mixture of p107 mAbs SD6 and SD15 (p107). Where indicated, immunoprecipitations were carried out in parallel with pl30 antibody preblocked with antigenic peptide $(\mathrm{p} 130+$ pep) or with an irrelevant mAb YS140 (MAb cont) as specificity controls. The resulting precipitates were then subjected to in vitro kinase reactions as described in Materials and methods and boiled in SDS release buffer, and the resulting soluble fractions reimmunoprecipitated with YS140 control mAb (MAb cont), anti E2F-4 mAb GG22 (E2F-4), anti-mouse DP-1 rabbit serum, R12 (DP-1), or the corresponding R12 preimmune serum (DP-1 p.i.) as indicated. The gel mobilities of prestained markers and their native molecular masses in $\mathrm{kD}$ are indicated at left.

protein was also present in p130/E2F-4 complexes (Fig. 1) and because DP-1 associated with E2F-1 is a substrate for cyclin A kinase (Dynlacht et al. 1994; Krek et al. 1994), we also asked whether phosphorylation of DPrelated proteins occurs in p130 immune complexes. Phosphorylation of an $\sim 45-\mathrm{kD}$ protein specifically recognized by anti-DP-1 immune serum, present in both p130 and p107 immune complexes from proliferating T cells, was detected (Fig. 4, lanes 13,15). These data therefore suggest that both E2F-4 and a DP subunit are in vitro substrates of $\mathrm{p} 130$ - and $\mathrm{p} 107$-associated kinases present in proliferating, but not quiescent, $\mathrm{T}$ cells.

\section{p130 represses E2F-4-dependent trans-activation}

To determine the functional significance of the $\mathrm{p} 130 /$ E2F-4 interaction, we examined the effect of introducing exogenous p130 upon the ability of E2F-4 to trans-activate an E2F-responsive promoter. Whereas E2F-4 efficiently trans-activated an adenovirus E2-chloramphenicol acetyltransferase (CAT) reporter plasmid when cotransfected into U2OS osteosarcoma cells (Fig. 5), addition of increasing quantities of a p130 expression plas- 


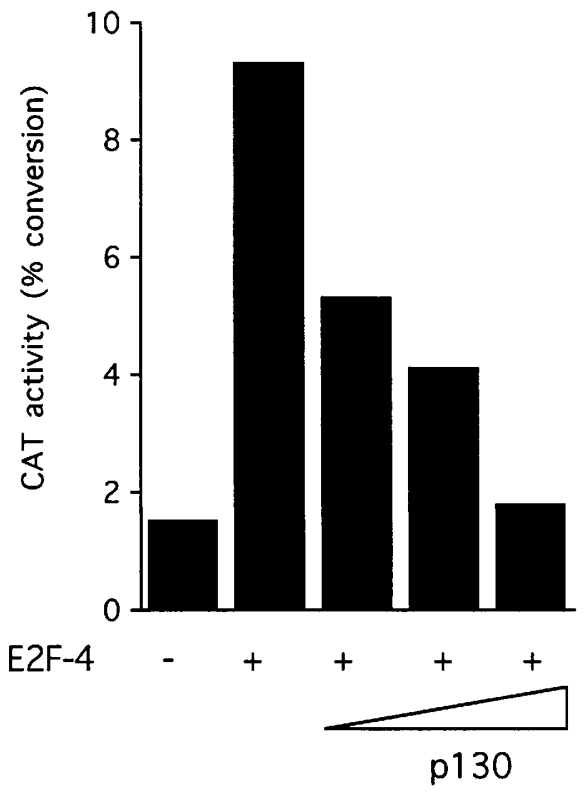

Figure 5. p130 represses E2F-4-mediated trans-activation. $\mathrm{U} 2 \mathrm{OS}$ cells were cotransfected, as indicated, with $5 \mu \mathrm{g}$ of an adenovirus E2-CAT E2F reporter plasmid (pE2wtCAT), pCMV $\beta$-GAL $(2 \mu \mathrm{g})$ as an internal control, pCMV-E2F-4 (500 $\mathrm{ng}$ ), plus 50,100 , or $500 \mathrm{ng}$ of a pCMV-driven p130 expression plasmid (pCDNA1-HAp130), using backbone pCMV vector as carrier. A total of $8 \mu \mathrm{g}$ of DNA was transfected in each case. CAT activities were determined for the various extracts, and the values were normalized for the corresponding $\beta$-galactosidase activity.

mid led to a progressive reduction in CAT activity (Fig. 5). Trans-activation of this reporter by E2F-4 has been demonstrated previously to require an intact E2F site (Ginsberg et al. 1994). p130 also suppressed an E2F-4dependent trans-activation of a B-myb promoter luciferase reporter when cotransfected into C33A cervical carcinoma cells. This effect occurred under conditions where p130 cotransfection resulted in no detectable change in cell cycle distribution of successfully transfected cells (assayed by CD19 coexpression; see below). Hence, trans-activation suppression is not attributable to an indirect cell cycle effect (data not shown).

\section{E2F-4 cotransfection overrides state of p130-induced $G_{1}$ arrest}

To determine whether overproduction of p130 can interfere with cell cycle progression, flow cytometry analysis of transfected SAOS-2 cells was performed. Cells were cotransfected with a pl30 expression plasmid and a plasmid encoding the cell surface protein, CD19. The CD19 protein was employed as a marker for separation of the successfully transfected cells from the untransfected ones, using an anti-CD19 monoclonal antibody, as in the past (Qin et al. 1992). Introduction of the CD19 plasmid, alone, did not affect cell cycle distribution of an acutely transfected culture (data not shown), whereas the p130 expression plasmid reproducibly led to a significant increase in the fraction of cells with a $G_{0} / G_{1}$ DNA content (Fig. 6). Cotransfection of p130 with E2F-4 led to a marked decrease in the percentage of CD19-positive cells in $G_{0} / G_{1}$ compared with that observed in cultures transfected with p130 alone. Cotransfection of p130 with another member of the E2F family, E2F-1, resulted in a less prominent reduction in the $G_{0} / G_{1}$ fraction, suggesting that E2F-4 is the more potent of the two E2Fs in overcoming a pl30-induced cell cycle arrest. This result has been reproduced in three independent experiments, and it is also consistent with the finding that p130 clearly associates with E2F-4 in preference to E2F-1 when overproduced in vivo (Fig $3 \mathrm{~d}$ ).

In keeping with results published previously /Goodrich et al. 1991; Hinds et al. 1992; Qin et al. 1992), introduction of RB into SAOS- 2 cells, in parallel with the pl30 transfection of aliquots of the same culture, also resulted in an increase in the fraction of cells in $G_{0} / G_{1}$. However, unlike what was observed when p130 was analyzed as a growthblocking agent, E2F-1 was active in overcoming growth suppression, whereas E2F-4 was inactive. In other experiments, however, E2F-4 had a weak override effect which was, nevertheless, consistently much less potent than that of E2F-1. In all cases, equal amounts of E2F-4 and E2F-1 plasmids were used, and in the experiment depicted in Fig-

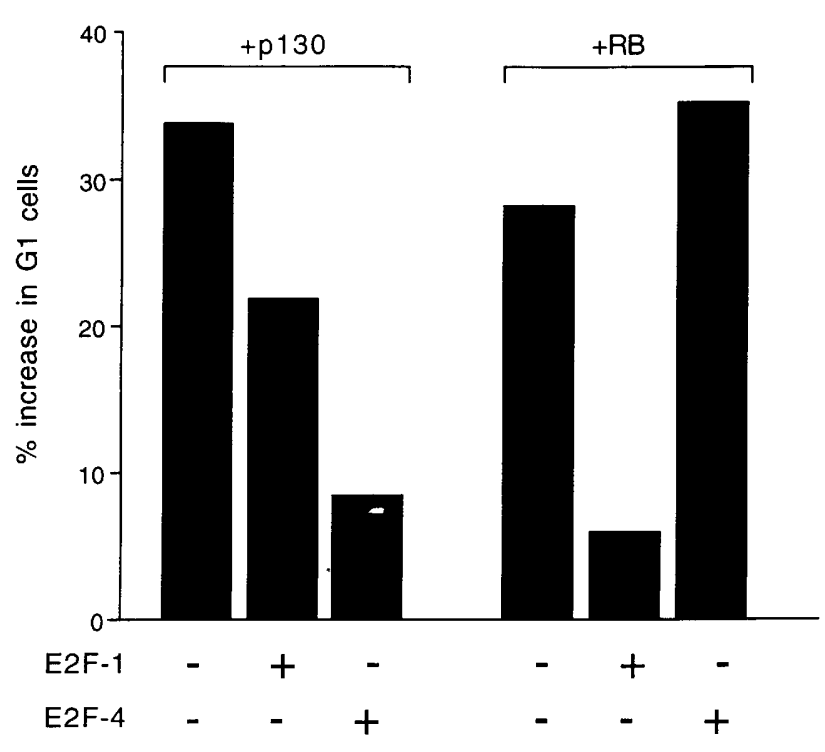

Figure 6. E2F-4 overrides p130-induced cell cycle arrest. SAOS- 2 cells were cotransfected, as indicated, with expression plasmids encoding CD19 $(2 \mu \mathrm{g})$, HApl30 $(8 \mu \mathrm{g})$, or RB $(8 \mu \mathrm{g})$, with or without $10 \mu \mathrm{g}$ of HAE2F-4 or E2F-1 expression plasmid, as indicated. Three days after transfection, cells were collected and stained for the presence of CD19. The cell cycle distribution of these cells was also determined, as described in Materials and methods. In cells solely transfected with the plasmid-encoding CD19, 50.9 of the cells were in $G_{0} / G_{1}$. The results shown represent the relative increases at each data point above this level. For example, p130 cotransfection with CD19 resulted in an absolute value of $68.1 \% \mathrm{G}_{0} / \mathrm{G}_{1}$ cells. This translates into a $33.8 \%$ relative increase in $G_{0} / G_{1}$ cells over the CD-19 control. 
ure 6, appropriate expression of the two E2Fs was detected by Western blotting analysis of extracts of the transfected cultures (data not shown). These results suggest that like $\mathrm{RB}, \mathrm{p} 130$ can also induce cell cycle arrest with an increased fraction of cells exhibiting a $G_{0} / G_{1}$ DNA content. However, the molecular mechanisms by which these two pocket proteins interfere with cell cycle progression are, most likely, not identical.

\section{Discussion}

In this paper E2F-4 was shown to be a partner for the RB family member, p130. Given the earlier results (Beijersbergen et al. 1994; Ginsberg et al. 1994|, E2F-4, therefore, binds to both p130 and p107 in vivo (Ginsberg et al. 1994) and is thus the first member of the E2F family to display affinity for multiple pocket proteins under physiological conditions. The interaction of E2F-4 with p130 has functional implications, because p130 suppressed E2F-4-mediated trans-activation and overproduction of E2F-4 prevented the growth arrest mediated by $\mathrm{p} 130$. The $\mathrm{G}_{1}$ block effected by p130 indicates that this protein can suppress growth. Moreover, this effect correlates with negative regulation of a defined E2F species. The differential ability of E2F-4 and E2F-1 to override the p130and RB-mediated $G_{1}$ blocks also reveals, for the first time, a functional difference between different E2F family members and suggests that p130 and RB may function to induce growth arrest via distinct molecular mechanisms. One might also speculate, in this regard, that E2F-1 and E2F-4 modulate the transcription, at least in part, of different promoters.

Unlike E2F-1, E2F-4 is synthesized throughout the cell cycle, with significant levels detected in $\mathrm{G}_{0}$ in both resting human $\mathrm{T}$ cells (Fig. 2) and serum-starved mouse fibroblasts (Ginsberg et al. 1994). Moreover, results presented here show that E2F-4 exists in complex with one pocket protein during $G_{0}$ and at least part of $G_{1}$ and another (p107) in late $G_{1}$ and $S$ (see also Cao et al. 1992; Lees et al. 1992; Shirodkar et al. 1992). Whether the same E2F-4 molecule is handed off from one pocket protein to another remains the subject of future inquiry.

In keeping with the notion that p130/E2F-4 complexes exist largely in $G_{0}$ and/or $G_{1}$, p107 was the predominant E2F-4 partner in cycling U937 leukemic cells (Figs. 1b and 3a), although small quantities of p130/E2F-4 complexes were still detected at those times (Fig. 3a). The finding that E2F-4 associated with p130 in a continually cycling cell population demonstrates that this interaction is not exclusive to $G_{0}$ cells or to cells entering the cell cycle from $G_{0}$, and, to some extent, probably occurs in part of $G_{1}$ (see also Cobrinik et al. 1993).

We also observed that in cycling U937 cells, the predominant free E2F activity corresponding to complex A [which is also evident in other cell types, including human T cells (Chittenden et al. 1993; data not shown)], was supershifted by E2F-4 antiserum. This suggests that E2F-4 is also a component of the major free E2F activity in cycling cells. It should be noted that $\mathrm{A}$ is not evident in extracts prepared from resting human T cells (Fig. la;
Chittenden et al. 1993), suggesting that free E2F-4 may arise after release from p130 in the G1 phase of cycling cells. Such a result is also consistent with the ability of overproduced E2F-4 to induce S-phase entry (Beijersbergen et al. 1994).

Several observations point to phosphorylation of E2F-4 as a potentially important regulatory mechanism for this transcription factor. First, as shown by its mobility in SDS gels, E2F-4 displayed dramatic heterogeneity because of differential phosphorylation in vivo that was, to some extent, regulated during entry of $G_{0} T$ cells into the cell cycle. Second, p130 and p107 interacted specifically with a more slowly migrating subset of phosphorylated E2F-4 than was detected in the total E2F-4 pool in vivo, suggesting that specific elements of the E2F-4 phosphorylation program can direct its interaction with these negative regulators. Implicit in this model is the assumption that such specific phosphorylation of E2F-4 facilitates its interaction with two negative regulators of its function. Notably, the fact that p130/ and p107/E2F-4 complexes scored positively in EMSAs implies that neither its specific phosphorylation nor its binding to pocket proteins leads to an inhibition of its DNA-binding function.

The in vivo mechanisms regulating E2F-4 phosphorylation remain to be determined. However, some clues to their nature exist. Endogenous E2F-4 was an in vitro substrate for p130-associated kinases in extracts of proliferating cells. Conceivably, this activity corresponds to one or both of the cyclin-dependent kinases known to interact with p130 in vivo (Fig. 4; see also Cobrinik et al. 1993; Li et al. 1993). In quiescent cells, however, in vitro kinase activity of this type was not detected. Nevertheless, p130-associated E2F-4 from $G_{0}$ cells and E2F-4 bound to p130 in proliferating cells displayed similar electrophoretic heterogeneity, suggesting that they were similarly phosphorylated. Because phosphorylated E2F-4 bound to p130 exists both in $\mathrm{G}_{0}$ and in cycling cells, but known p130- cyclin/kinase complexes do not exist in $\mathrm{G}_{0}$, E2F-4, phosphorylated de novo in $\mathrm{G}_{0}$, cannot be phosphorylated by known p130-bound kinases like cyclin E or A kinase (Cobrinik et al. 1993; Hannon et al. 1993; Li et al. 1993). Conceivably, there are other kinases, yet to be identified, which bind to p130 in $\mathrm{G}_{0}$ cells. However, we failed to detect them in the in vitro kinase assays described in Figure 4.

A number of possible mechanisms could be invoked to account for the increased mobility of E2F-4 observed following mitogenic stimulation of $\mathrm{T}$ cells (Fig. 2), including E2F-4 dephosphorylation by cell cycle-dependent phosphatase activation or failure of phosphorylation of newly synthesized E2F-4 attributable to inactivation of a $\mathrm{G}_{0}$-specific kinase coupled with degradation of preexisting phospho-E2F-4. The identification of a novel phosphatase that associates with $\mathrm{RB}$ in vivo provides a precedent for the concept of pocket protein-associated phosphatases (Durfee et al. 1993).

With the data presented here, one can now propose the outlines of a generic model for p130 and E2F-4 function in cell cycle control. We have shown that E2F-4 and p130 are components of a $\mathrm{G}_{0}$ complex in quiescent primary 
human $\mathrm{T}$ cells and that $\mathrm{p} 130$ has a growth-suppressive function that can be overcome, in a relatively specific manner, by overproduction of E2F-4 that is, itself, capable of promoting $\mathrm{G}_{1} / \mathrm{S}$-phase transit (Beijersbergen et al. 1994). Thus, E2F-4 can function downstream of p130, and p130 growth arrest may involve suppression of E2F-4 activity. Overproduction of E2F-1 was not as potent as overproduction of E2F-4 in overriding p130-induced growth arrest. This was the case, despite the fact that E2F-1 does not interact with pl30 in vivo and is, therefore, presumed to be present largely as free E2F-1 in p130-cotransfected cells. These results suggest that E2F-1 and E2F-4 target different, although perhaps overlapping, sets of E2F-regulated promoters. By analogy with what is known of the effect of pRB on E2F-1 (Weintraub et al. 1992; Helin et al. 1993a; Flemington et al. 1993; Qin et al. 1995; W.R. Sellers, J. Rodgers, and W.G. Kaelin, in prep.), binding of p130 to E2F-4 in $\mathrm{G}_{0}$ might result in the suppression of E2F-4 target genes during quiescence. By specifically repressing certain E2F target genes that can initiate and/or perpetuate cell cycle progression, it is possible that formation of a p130/E2F-4 complex plays an active role in inducing and/or maintaining cellular quiescence. Such a model would speak to at least one aspect of the control mechanisms operating at the $G_{0} / G_{1}$ transition.

This proposal is supported by the fact that the E2F sites present in the promoters of certain E2F-regulated genes, such as B-myb, $c d c 2$, or even E2F-1 itself, are required for the repression of these genes during $G_{0} / G_{1}$ (Dalton 1992; Lam et al. 1993; Hsiao et al. 1994; Neuman et al. 1994). Again, by analogy with what happens to $\mathrm{pRB} / \mathrm{E} 2 \mathrm{~F}-1$ complexes during $\mathrm{G}_{1}$ exit, a signal leading to $\mathrm{G}_{0}$ exit may result in E2F-4 being freed from p130 (perhaps via phosphorylation mediated by one or more cyclin/cdk species) with subsequent derepression/activation of E2F-4 target genes. Such a proposal is consistent with detection of free E2F-4 in cycling, but not quiescent $T$ cells and the ability of E2F-4 overexpression to induce S-phase entry in the face of pl30 cotransfection. Conceivably, the E2F-4 interaction with p107, which clearly occurs later in $G_{1}$ or at $G_{1} / S$ /Cao et al. 1992; Lees et al. 1992; Shirodkar et al. 1992), serves to regulate negatively E2F-4 at later times in the cycle.

Whatever the case, the fact that two related pocket proteins interact with the same transcription factor sequentially in the cell cycle implies that the functional consequences of these two sets of interactions are not identical. Among the potential effects of the processive binding of E2F-4 by p130 and p107 is the serial activation and repression of certain E2F-dependent genes during the period of progression out of $G_{0}$ and into $S$. This and other possibilities must be the subject of future investigations.

\section{Materials and methods}

\section{Cell culture}

C33A cervical carcinoma cells and U2OS and SAOS2 osteosarcoma cell lines were grown in Dulbecco's modified Eagle me- dium (DMEM) with $10 \%$ fetal calf serum (FCS, Hyclone) at $37^{\circ} \mathrm{C}$ in a $10 \% \mathrm{CO}_{2}$-containing atmosphere. The U937 human promonocytic leukemic cell line was cultured in RPMI-1640 $10 \% \mathrm{FCS}$ at $37^{\circ} \mathrm{C}$ and $5 \% \mathrm{CO}_{2}$. Primary human $\mathrm{T}$ cells from peripheral blood of healthy donors were isolated as described previously (Chittenden et al. 1993). Briefly, T cells were prepared by Ficoll/Hypaque (Pharmacia) gradient centrifugation, and adherent cells were removed by incubation on plastic for 2 hr. Where indicated, $\mathrm{T}$ cells in RPMI-1640-10\% FCS at $37^{\circ} \mathrm{C}$ and $5 \% \mathrm{CO}_{2}$ were stimulated by the addition of $1 \mu \mathrm{g} / \mathrm{ml}$ of PHA for the indicated times prior to use.

\section{Whole cell extracts and EMSAs}

Whole-cell extracts from primary human T cells or U937 cells were prepared as described previously (Raychaudhuri et al. 1987; Shirodkar et al. 1992). Extract (10 $\mu \mathrm{g})$ was used for EMSA and electrophoresed in $4 \%$ nondenaturing polyacrylamide gels, as described previously (Shirodkar et al. 1992; Chittenden et al. 1993). The probe used was a ${ }^{32} \mathrm{P}$-end labeled, double-stranded oligonucleotide corresponding to the -82 to -40 sequence of the human c-myc P2 promoter (Cobrinik et al. 1993). For competition studies, a 100-fold molar excess of unlabeled probe was included. For these studies, in addition to the c-myc probe, oligonucleotides corresponding to the E2F site derived from the dihydrofolate reductase promoter, (DHFR; wild type) or an E2F site mutant of this probe, DHFR (mutant), were also used as competitors (Shirodkar et al. 1992).

\section{Western analysis}

Whole-cell extracts, prepared as described above, were subjected to electrophoresis ( $200 \mu \mathrm{g}$ of cellular protein per lane) using $8 \%$ polyacrylamide-SDS gels. After transfer to Hybond-C extra (Amersham), the membranes were blocked for 4-6 hr with 5\% nonfat milk in Tris-buffered saline (pH 8.0) (TBS), washed, and incubated overnight at $4^{\circ} \mathrm{C}$ with a 1:10 dilution of E2F-4 mAb GG22, hybridoma tissue culture supernatant in TBS/3\% BSA. After washing with $0.05 \%$ Tween 20 in TBS, immunoblots were incubated with horseradish peroxidase-conjugated rabbit antimouse IgG and the bands were visualized by enhanced chemiluminescence, according to manufacturer's instructions (Amersham).

\section{Metabolic labeling and immunoprecipitations}

Cells were incubated in methionine-free DMEM (GIBCO) with $10 \%$ dialyzed FCS (GIBCO) for $\sim 30$ min prior to labeling for $4 \mathrm{hr}$ in the same medium containing $\left[{ }^{35} \mathrm{~S}\right]$ methionine $(2-3 \mathrm{mCi} / 4 \mathrm{ml}$ in a $10-\mathrm{cm}$ dish for adherent cells or $1 \mathrm{mCi} / \mathrm{ml}$ for suspension cultures at $10^{7}$ cells $/ \mathrm{ml}$. After washing with cold phosphatebuffered saline (PBS), cells were lysed in TNN buffer $(50 \mathrm{mM}$ Tris- $\mathrm{HCl}$ at $\mathrm{pH} 7.4,120 \mathrm{~mm} \mathrm{NaCl}, 5 \mathrm{mM}$ EDTA, $0.5 \% \mathrm{NP}-40,50$ $\mathrm{mM} \mathrm{NaF}, 0.2 \mathrm{mM}$ sodium orthovanadate, $1 \mathrm{mM}$ DTT, $1 \mathrm{~mm}$ PMSF, $20 \mu \mathrm{g} / \mathrm{ml}$ of aprotinin) using $1 \mathrm{ml} / 10-\mathrm{cm}$ dish for adherent cells or $1 \mathrm{ml} / 10^{7}$ suspension cells. The lysate was centrifuged at $4^{\circ} \mathrm{C}$ for $10 \mathrm{~min}$ at $10,000 \mathrm{~g}$. Following preclearing for 30 min with protein A-Sepharose (Pharmacia), supernatants were incubated on a rocker for $1 \mathrm{hr}$ at $4{ }^{\circ} \mathrm{C}$ with the indicated antibodies [for immunoprecipitations using mouse monoclonal antibodies, rabbit anti-mouse IgG secondary antibody (Cappel) was added for the final $30 \mathrm{~min}$ ] Fifty microliters of a 50\% (wt/ vol) slurry of protein A-Sepharose was then added, and the incubation continued for $30 \mathrm{~min}$. Immune complexes were collected by centrifugation and washed four times with TNN buffer. For reprecipitations, washed immunobeads were boiled 
for $10 \mathrm{~min}$ in $100 \mu \mathrm{l}$ of $1 \times$ SDS release buffer $(50 \mathrm{~mm}$ Tris $\mathrm{HCl}$ at $\mathrm{pH} 7.5,1 \% \mathrm{SDS}$, and $5 \mathrm{~mm} \mathrm{DTT})$, and $10 \mu \mathrm{l}$ of this was set aside as a control for the first immunoprecipitation. The remainder was diluted to $1.4 \mathrm{ml}$ with TNN buffer and the indicated antibodies, and the resulting mixture was incubated overnight at $4^{\circ} \mathrm{C}$. Immune complexes were then collected and treated, as described above. Samples were resuspended in SDS sample buffer, boiled, separated by electrophoresis in $8 \%$ SDSpolyacrylamide gels, and visualized by fluorography. The calculated molecular masses, noted in the text, were determined using the apparent molecular masses of the prestained markers.

For immunoprecipitations of in vitro-translated (IVT) HAtagged E2F species, $\left[{ }^{35} \mathrm{~S}\right]$ Methionine-labeled translation products were prepared with the TNT lysate system (Promega) according to the manufacturer's instructions. Translated proteins (5 $\mu$ l) were immunoprecipitated, as above, except that TNN containing $250 \mathrm{~mm} \mathrm{NaCl}$ was used. The final two washes were with TNN containing $1 \mathrm{M} \mathrm{NaCl}$.

\section{Phosphatase treatment}

Immunoprecipitates, prepared as described above, were washed once and resuspended in $60 \mu \mathrm{l}$ of phosphatase buffer (see NEB specifications). Lambda phosphatase (500 units) (NEB) was added to the appropriate tubes and incubated at $30^{\circ} \mathrm{C}$ for $1 \mathrm{hr}$. Where indicated, the phosphatase inhibitors vanadate $(10 \mathrm{mM})$ and $\mathrm{NaF}(5 \mathrm{~mm})$ were included as specificity controls.

\section{In vitro kinase assay}

Lysates from resting and stimulated $\mathrm{T}$ cells were prepared in TNN as above and total cellular protein concentrations determined (Bio-Rad). Equivalent amounts of total cellular protein were immunoprecipitated as above. After washing with lysis buffer, beads were washed once more with kinase buffer $(50 \mathrm{mM}$ HEPES at $\mathrm{pH} 7.0,10 \mathrm{mM} \mathrm{MgCl}_{2}, 5 \mathrm{~mm} \mathrm{MnCl}$, and $1 \mathrm{mM} \mathrm{DTT)}$ and then incubated with $30 \mu \mathrm{l}$ of kinase buffer containing 10 $\mu \mathrm{Ci}\left[\gamma^{32} \mathrm{P} \mid \mathrm{ATP}(\mathrm{NEN})\right.$ for $20 \mathrm{~min}$ at $37^{\circ} \mathrm{C}$. The reaction was terminated by addition of $30 \mu \mathrm{l}$ of $2 \times$ SDS release buffer (see abovel, boiled, diluted, reimmunoprecipitated for $1-2 \mathrm{hr}$ as described above and subjected to electrophoresis in $8 \%$ polyacrylamide-SDS gels and visualized by autoradiography.

\section{Plasmids}

pCDNA1-HAp130, the first 96 nucleotides of a pl30 clone [pBS(S) F-130 1-4853] (Li et al. 1993) were replaced with a PCR product spanning this region containing an in-frame BamHI site and a consensus Kozak sequence introduced immediately $5^{\prime}$ of the initiating ATG codon. The DNA sequence of the PCR-derived region was verified by sequencing. A 3488-bp BamHI$X b a I$ fragment containing the full-length p130 open reading frame was cloned into pCDNAl(HAE2F-1) (Krek et al. 1993) from which the E2F-1 cDNA was excised by BamHI-XbaI digestion to generate an expression plasmid encoding an aminoterminal HA-tagged full-length p130-encoding plasmid.

Other plasmids used here have been described previously: pcDNA1-HAE2F-1, pcDNA1-HAE2F-2, pcDNA1-HAE2F-3, pCMV-E2F-1 (Krek et al. 1994); pCMV-p107 (Zhu et al. 1993); pE2wtCAT (wtE2) (Helin et al. 1992); pCMV-Rb (Qin et al. 1992); pCMV-HAE2F-4 and pCMV-E2F-4 (Ginsberg et al. 1994).

\section{Transient transfections}

Cells were transfected by a modified calcium-phosphate protocol (Qin et al. 1992). For E2F trans-activation assays, cells were harvested $40 \mathrm{hr}$ after transfection and lysed by three cycles of freeze-thawing in $100 \mu$ l of $250 \mathrm{~mm}$ Tris- $\mathrm{HCl}(\mathrm{pH} 8.0)$. Extracts were assayed for $\beta$-galactosidase and CAT activities, as described previously (Krek et al. 1993; Ginsberg et al. 1994).

\section{Flow cytometric analysis}

The effects of pocket protein or E2F expression on cell cycle distribution were determined as described previously [Qin et al. 1992). Briefly, SAOS2 cells were cotransfected with $2 \mu \mathrm{g}$ of CD19 expression plasmid (pCMV-CD19) (kindly provided by $\mathrm{T}$. Tedder, Duke University, Durham, NC) together with the various combinations of cytomegalovirus (CMV)-driven expression plasmids encoding p130, RB, E2F-4, E2F-1. Backbone CMV vector was added such that all cultures were treated with equal total amounts of plasmid DNA. Eighteen hours after transfection, the cells were washed and incubated at $37^{\circ} \mathrm{C}$ for 2 more days prior to trypsinization and FITC staining for surface expression of CD19 and propidium iodide DNA staining. The cell cycle distribution of CD19-positive cells was determined by FACs analysis using SOBR cell cycle analysis software.

\section{Antibodies}

Affinity-purified rabbit p130 antibody raised against a peptide corresponding to the carboxy-terminal 20 amino acids of p130 (C20) (catalog no. sc-317) was obtained from Santa Cruz Biotechnology. One microgram of this was added per immunoprecipitation reaction or per $25 \mu \mathrm{l}$ EMSA reaction. Where indicated, the antibody was preblocked by mixing with antigenic peptide (Santa Cruz) ( $1 \mu \mathrm{g}$ of peptide/ $\mu \mathrm{g}$ of antibody) at $4^{\circ} \mathrm{C}$ for 15 min prior to use. p107 monoclonal antibody (SD2, SD6, SD9, and SD15) hybridoma tissue culture supernatants, kindly provided by N. Dyson (Massachusetts General Hospital, Boston, MAl, were used for immunoprecipitations as indicated at $100 \mu \mathrm{l}$ per immunoprecipitation reaction or at $2 \mu \mathrm{l}$ per EMSA reaction. The E2F-4 mAbs, GG22 and GG21, generated as described previously (Ginsberg et al. 1994), were used at $100 \mu$ l of hybridoma tissue culture supernantant per immunoprecipitation reaction. Mouse polyclonal antiserum to human E2F-4, obtained from the immunized BALB/c mouse whose spleen was used to generate the monoclonal antibodies above, was used at $0.8 \mu \mathrm{l}$ per gel shift reaction or $1 \mu l$ per immunoprecipitation reaction. Rabbit polyclonal antiserum to murine DP-1 (R12), kindly provided by S. Shirodkar (Dana-Farber Cancer Institute, Boston, MA), was raised against full-length (Girling et al. 1993) glutathione $S$-transferase (GST)-fusion protein and was used at $4 \mu \mathrm{l}$ per immunoprecipitation reaction or $1 \mu l$ per EMSA reaction. Mouse polyclonal antiserum to human DP-1, raised in BALB/c mice against a GST-fusion protein encompassing amino acids $1-400$ of the human DP-1 gene product, was used at $0.8 \mu \mathrm{l}$ per gel shift reaction. Affinity-purified anti-human E2F-1 mAb SQ41, kindly provided by W. Kaelin and J. DeCaprio (DanaFarber Cancer Institute, Boston, MA), was used at $1.4 \mu \mathrm{g}$ per immunoprecipitation reaction. Control monoclonal antibody (anti-cdc10) YS140 and YS146 hybridoma tissue culture supernatants were kindly provided by J. Ayte (Dana-Farber Cancer Institute, Boston, MA) and J. DeCaprio. Affinity-purified antiCD19 mAb CD19.15 (kindly provided by $T$. Tedder) was used at 1:500 dilution. FITC-conjugated goat anti-mouse secondary antibody (used at $15 \mu \mathrm{g} / \mathrm{ml}$ ) was purchased from Boerhinger Mannheim. Affinity-purified anti-HA antibody consisted of either a rabbit polyclonal antibody or mAb 12CA5, from BAbCo.

\section{Acknowledgments}

We are grateful to Drs James DeCaprio, Mark Ewen, William 
Kaelin, Wilhelm Krek, Joe Leis, and Suman Shirodkar for helpful discussions. We thank Dr. Peter Whyte for p130 cDNA; Dr. N. Dyson for anti p107 antibodies; Dr. Liang Zhu for plasmid, pCMVp107; Dr. Thomas Tedder for pCD19: Dr. John Gribben for anti-CD19 antibody, Dr. Yutaka Hoshikawa for help with T-cell preparations, and Dr. Suman Shirodkar for anti-DP-1 polyclonal antibody. We thank Drs. C. Sardet and R.A. Weinberg for sharing unpublished data. G.V. is a recipient of a National Health and Medical Research Council of Australia-C.J. Martin postdoctoral fellowship. D.G. was supported by a postdoctoral fellowship from the Damon Runyon-Walter Winchell Cancer Research Fund (DRG-1202). This work was supported by grants from the National Institutes of Health and from the Sandoz Drug Discovery Program.

The publication costs of this article were defrayed in part by payment of page charges. This article must therefore be hereby marked "advertisement" in accordance with 18 USC section 1734 solely to indicate this fact.

\section{References}

Bandara, L.R., V.M. Buck, M. Zamanian, L.H. Johnston, and N.B. La Thangue. 1993. Functional synergy between DP-1 and E2F-1 in the cell cycle regulating transcription factor DRTF1/E2F. EMBO I. 12: 4317-4324.

Bandara, L.R., E.W.-F. Lam, T.S. Sorensen, M. Zamanian, R. Girling, and N.B. La Thangue. 1994. DP-1: A cell cycle-reg ulated and phosphorylated component of transcription factor DRTF1/E2F which is functionally important for recognition by $\mathrm{pRb}$ and the adenovirus $\mathrm{E} 4$ orf $6 / 7$ protein. $E M B O$ I. 13: 3104-3114.

Beijersbergen, R.L., R.M. Kerkhoven, L. Zhu, L. Carlee, F.M. Mathijs, and R. Bernards. 1994. E2F-4, a new member of the E2F gene family, has oncogenic activity and associates with p107 in vivo. Genes \& Dev. 8: 2680-2690.

Buchkovich, K., L.A. Duffy, and E. Harlow. 1989. The retinoblastoma protein is phosphorylated during specific phases of the cell cycle. Cell 58: 1097-1105.

Cao, L., B. Faha, M. Dembski, L.-H. Tsai, E. Harlow, and N. Dyson. 1992. Independent binding of the retinoblastoma protein and p107 to the transcription factor E2F. Nature 355: 176-179.

Chellappan, S.P., S. Hiebert, M. Mudryi, J.M. Horowitz, and J.R. Nevins. 1991. The E2F transcription factor is a cellular target for the RB protein. Cell 65: 1053-1061.

Chen, P., P. Scully, J. Shew, J.Y.J. Wang, and W. Lee. 1989. Phosphorylation of the retinoblastoma gene product is modulated during the cell cycle and cellular differentiation. Cell 58: 1193-1198.

Chittenden, T., D.M. Livingston, and J.A. DeCaprio. 1993. Cell cycle analysis of E2F in primary human $T$ cells reveals novel E2F complexes and biochemically distinct forms of "free" E2F. Mol. Cell. Biol. 13: 3975-3983.

Cobrinik, D., P. Whyte, D.S. Peeper, T. Jacks, and R.A. Weinberg. 1993. Cell cycle-specific association of E2F with the p130 ElA binding protein. Genes \& Dev. 7: 2392-2404.

Dalton, S. 1992. Cell cycle regulation of the human cdc2 gene. EMBO I. 11: 1797-1804.

DeCaprio, J.A., J.W. Ludlow, D. Lynch, Y. Furukawa, J. Griffin, H. Piwnica-Worms, C.-M. Huang, and D.M. Livingston. 1989. The product of the retinoblastoma susceptibility gene has properties of a cell cycle regulatory element. Cell 58: $1085-1095$.

Devoto, S.H., M. Mudryi, J. Pines, T. Hunter, and J.R. Nevins. 1992. A cyclin A protein kinase complex possesses sequence specific DNA binding activity; p33cdk2 is a component of the E2F-Cyclin A complex. Cell 68: 167-176.

Durfee, T., K. Becherer, P.-L. Chen, S.-H. Yeh, Y. Yang, A.E. Kilburn, W.-H. Lee, and S.J. Elledge. 1993. The retinoblastoma protein associates with the protein phosphatase type 1 catalytic subunit. Genes \& Dev. 7: 555-569.

Dynlacht, B.D., O. Flores, J.A. Lees, and E. Harlow. 1994. Differential regulation of E2F trans-activation by cyclin/cdk2 complexes. Genes \& Dev. 8: 1772-1786.

Dyson, N., M. Dembski, A. Fattaey, C. Ngwu, M. Ewen, and K. Helin. 1993. Analysis of p107-associated proteins: p107 associates with a form of E2F that differs from $\mathrm{pRb}$-associated E2F-1. J. Virol. 67: 7641-7647.

Ewen, M.E. 1994. The cell cycle and the retinoblastoma protein family. Cancer Metastas. Rev. 13: 45-66.

Ewen, M.E., B. Faha, E. Harlow, and D.M. Livingston. 1992. Interaction of p107 with cyclin A independent of complex formation with viral oncoproteins. Science 255: 85-87.

Faha, B., M. Ewen, L. Tsai, D.M. Livingston, and E. Harlow. 1992. Interaction between human cyclin $A$ and adenovirus ElA-associated pl07 protein. Science 255: 87-90.

Flemington, E.K., S.H. Speck, and W.G. Kaelin. 1993. E2F-1 mediated transactivation is inhibited by complex formation with the retinoblastoma susceptibility gene product. Proc. Natl. Acad. Sci. 90: 6914-6918.

Ginsberg, D., G. Vairo, T. Chittenden, Z.-X. Xiao, G. Xu, K.L. Wydner, J.A. DeCaprio, J.B. Lawrence, and D.M. Livingston. 1994. E2F-4, a new member of the E2F transcription factor family, interacts with pl07. Genes \& Dev. 8: 26652679.

Girling, R., J.F. Partridge, L.R. Bandara, N. Burden, N.F. Totty, J.J. Hsuan, and N.B. La Thangue. 1993. A new component of the transcription factor DRTF1/E2F 1. Nature 362: 83-87.

Goodrich, D.W., N.P. Wang, Y.-W. Qian, E.Y.-H.P. Lee, and W.-H. Lee. 1991. The retinoblastoma gene product regulates progression through the G1 phase of the cell cycle. Cell 67: 293-302.

Hamel, P.A., R.M. Gill, R.A. Phillips, and B.L. Gallie. 1992. Transcriptional repression of the E2-containing promoters EIIaE, c-myc, and RBl by the product of the RBl gene. Mol. Cell. Biol. 12: 3431-3438.

Hannon, G.J., D. Demetrick, and D. Beach. 1993. Isolation of the $\mathrm{Rb}$-related p130 through its interaction with CDK2 and cyclins. Genes \& Dev. 7: 2378-2391.

Helin, K., J.A. Lees, M. Vidal, N. Dyson, E. Harlow, and A. Fattaey. 1992. A cDNA encoding a pRB-binding protein with properties of the transcription factor E2F. Cell 70: 337-350.

Helin, K., E. Harlow, and A. Fattaey. 1993a. Inhibition of E2F-1 transactivation by direct binding of the retinoblastoma protein. Mol. Cell. Biol. 13: 6501-6508.

Helin, K., C.L. Wu, A.R. Fattaey, J.A. Lees, B.D. Dynlacht, C. $\mathrm{Ngwu}$, and E. Harlow. 1993b. Heterodimerization of the transcription factors E2F-1 and DP-1 leads to cooperative trans-activation. Genes \& Dev. 7: 1850-1861.

Hiebert, S.W., M. Blake, J. Azizkhan, and J.R. Nevins. 1991. Role of E2F transcription factor in E1A-mediated transactivation of cellular genes. J. Virol. 65: 3547--3552.

Hiebert, S.W., S.P. Chellappan, I.M. Horowitz, and J.R. Nevins. 1992. The interaction of RB with E2F coincides with an inhibition of the transcriptional activity of E2F. Genes \& Dev. 6: $177-185$.

Hinds, P.W., S. Mittnacht, V. Dulic, A. Arnold, S.I. Reed, and R.A. Weinberg. 1992. Regulation of retinoblastoma protein functions by ectopic expression of human cyclins. Cell 70: 993-1006.

Hsiao, K.-M., S.L. McMahon, and P.J. Farnham. 1994. Multiple DNA elements are required for the growth regulation of the 
mouse E2F1 promoter. Genes \& Dev. 8: 1526-1537.

Ivey-Hoyle, M., R. Conroy, H. Huber, P.J. Goodhart, A. Oliff, and D.C. Heimbrook. 1993. Cloning and characterization of E2F-2, a novel protein with the biochemical properties of transcription factor E2F. Mol. Cell. Biol. 13: 7802-7812.

Kaelin, W.G.J., W. Krek, W.R. Sellers, J.A. DeCaprio, F. Ajchenbaum, C.S. Fuchs, T. Chittenden, Y. Li, P.J. Farnham, M.A. Blanar, D.M. Livingston, and E.K. Flemington. 1992. Expression cloning of a cDNA encoding a retinoblastoma-binding protein with E2F-like properties. Cell 70: 351-364.

Krek, W., D.M. Livingston, and S. Shirodkar. 1993. Binding to DNA and the retinoblastoma gene product by complex formation of different E2F family members. Science 262: 15571560.

Krek, W., M.E. Ewen, S. Shirodkar, Z. Arany, W.G. Kaelin Jr., and D.M. Livingston. 1994. Negative regulation of the growth-promoting transcription factor E2F-1 by a stably bound cyclin A-dependent protein kinase. Cell 78: 161-172.

Lam, E.W.-F. and R.J. Watson. 1993. An E2F-binding site mediates cell-cycle regulated repression on mouse B-myb transcription. EMBO I. 12: 2705-2713.

La Thangue, N.B. 1994. DRTF1/E2F: An expanding family of heterodimeric transcription factors implicated in cell-cycle control. Trends Biochem. Sci. 19: 108-114.

Lees, E., B. Faha, V. Dulic, S.I. Reed, and E. Harlow. 1992. Cyclin $\mathrm{E} / \mathrm{cdk} 2$ and cyclin A/cdk2 kinases associate with p107 and E2F in a temporally distinct manner. Genes \& Dev. 6: 1874 1885.

Lees, J.A., M. Saito, M. Vidal, M. Valentine, T. Look, E. Harlow, N. Dyson, and K. Helin. 1993. The retinoblastoma protein binds to a family of E2F transcription factors. Mol. Cell. Biol. 13: 7813-7825.

Li, Y., C. Graham, S. Lacy, M.V. Duncan, and P. Whyte. 1993. The adenovinus $\mathrm{E} 1 \mathrm{a}$-associated $130-\mathrm{kD}$ protein is encoded by a member of the retinoblastoma gene family and physically interacts with cyclins A and E. Genes \& Dev. 7: 2366-2377.

Li, Y., J.E. Slansky, D.J. Myers, N.R. Drinkwater, W.G. Kaelin, and P.J. Farham. 1994. Cloning, chromosomal location, and characterization of mouse E2F1. Mol. Cell. Biol. 13: 16101618.

Mayol, X., X. Grana, A. Baldi, N. Sang, Q. Hu, and A. Giordano. 1993. Cloning of a new member of the retinoblastoma gene family (pRb2) which binds to the E1A transforming domain. Oncogene 8: 2561-2566.

Mihara, K., X. Cao, A. Yen, S. Chandler, B. Driscoll, A.L. Murphree, A. T'Ang, and Y. Fung. 1989. Cell cycle-dependent regulation of phosphorylation of the human retinoblastoma gene product. Science 246: 1300-1303.

Mudryj, M., S.W. Hiebert, and J.R. Nevins. 1990. A role for the adenovirus inducible E2F transcription factor in a proliferation dependent signal transduction pathway. EMBO $J$. 9: 2179-2184.

Neuman, E., E.K. Flamington, W.R. Sellers, and W.G. Kaelin. 1994. transcription of the E2F-1 gene is rendered cell cycle dependent by E2F DNA-binding sites within its promoter. Mol. Cell. Biol. 14: 6607-6615.

Nevins, J.R. 1992. E2F: A link between the Rb tumor supressor protein and viral oncoproteins. Science 258: 424-429.

Pardee, A.B. 1989. G1 events and regulation of cell proliferation. Science 246: 603-608.

Peter, M. and I. Herskowitz. 1994. Joining the complex: Cyclindependent kinase inhibitory proteins and the cell cycle. Cell 79: 181-184.

Qin, X.-Q., T. Chittenden, D.M. Livingston, and W.G. Kaelin. 1992. Identification of a growth suppression domain within the retinoblastoma gene product. Genes \& Dev. 6: 953-964.
Qin, X.-Q., D.M. Livingston, M.E. Ewen, W.R. Sellers, Z. Arany, and W.G. Kaelin. 1995. The transcription factor E2F-1 is a downstream target of RB action. Mol. Cell. Biol. 15: 742755.

Raychaudhuri, P., R. Rooney, and I.R. Nevins. 1987. Identification of an E1A-inducible cellular factor that interacts with regulatory sequences within the adenovirus E4 promoter. EMBO I. 6: 4073-4081.

Sardet, C., M. Vidal, D. Cobrinik, Y. Geng, C. Onufryk, A. Chen, and R.A. Weinberg. 1995. E2F-4 and E2F-5, two novel members of the E2F family, are expressed in the early phases of the cell cycle. Proc. Natl. Acad. Sci. (in press).

Schwarz, J.K., S.H. Devoto, E.J. Smith, S.P. Chellappan, L. Jakoi, and J.R. Nevins. 1993. Interactions of the pl07 and Rb proteins with E2F during the cell proliferation response. $E M B O$ J. 12: 1013-1020.

Shan, B., X. Zhu, P.-L. Chen, T. Durfee, Y. Yang, D. Sharp, and W.-H. Lee. 1992. Molecular cloning of cellular genes encoding retinoblastoma-associated proteins: Identification of a gene with properties of the transcription factor E2F. Mol. Cell. Biol. 12: 5620-5631.

Sherr, C.J. 1993. Mammalian G1 cyclins. Cell 73: 1059-1065.

Shirodkar, S., M. Ewen, J.A. DeCaprio, J. Morgan, D.M. Livingston, and T. Chittenden. 1992. The transcription factor E2F interacts with the retinoblastoma product and a pl07-cyclin A complex in a cell cycle-regulated manner. Cell 68: 157166.

Slansky, J.E., Y. Li, W.G. Kaelin, and P.J. Farnham. 1993. A protein synthesis-dependent increase in E2F1 mRNA correlates with growth regulation of the DHFR promoter. Mol. Cell. Biol. 13: 1610-1618.

Thalmeier, K., H. Synovzik, R. Mertz, E.-L. Winnacker, and M. Lipp. 1989. Nuclear factor E2F mediates basic transcription and trans-activation by E1A of the human MYC promoter. Genes \& Dev. 3: 527-536.

Weintraub, S.J., C.A. Prater, and D.C. Dean. 1992. Retinoblastoma protein switches the $\mathrm{E} 2 \mathrm{~F}$ site from positive to negative element. Nature 358: 259-261.

Yeung, R.S., D.W. Bell, J.R. Testa, X. Mayol, A. Baldi, X. Grana, K. Klinga-Levan, A.G. Knudson, and A. Giordano. 1993. The retinoblastoma-related gene, RB2, maps to human chromosome $16 \mathrm{q} 12$ and rat chromosome 19. Oncogene 8: 34653468.

Zamanian, M. and N.B. La Thangue. 1992. Adenovirus E1A prevents the retinoblastoma gene product from repressing the activity of a cellular transcription factor. EMBO J. 11: 26032610.

Zhu, L., S. van der Heuvel, K. Helin, A. Fattaey, M. Ewen, D. Livingston, N. Dyson, and E. Harlow. 1993. Inhibition of cell proliferation by p107, a relative of the retinoblastoma protein. Genes \& Dev. 7: 1111-1125. 


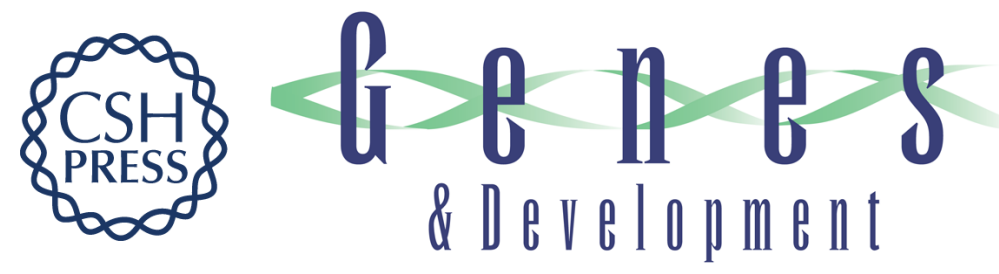

\section{Functional interaction between E2F-4 and p130: evidence for distinct mechanisms underlying growth suppression by different retinoblastoma protein family members.}

G Vairo, D M Livingston and D Ginsberg

Genes Dev. 1995, 9:

Access the most recent version at doi:10.1101/gad.9.7.869

References This article cites 61 articles, 32 of which can be accessed free at: http://genesdev.cshlp.org/content/9/7/869.full.html\#ref-list-1

License

Email Alerting Service

Receive free email alerts when new articles cite this article - sign up in the box at the top right corner of the article or click here.

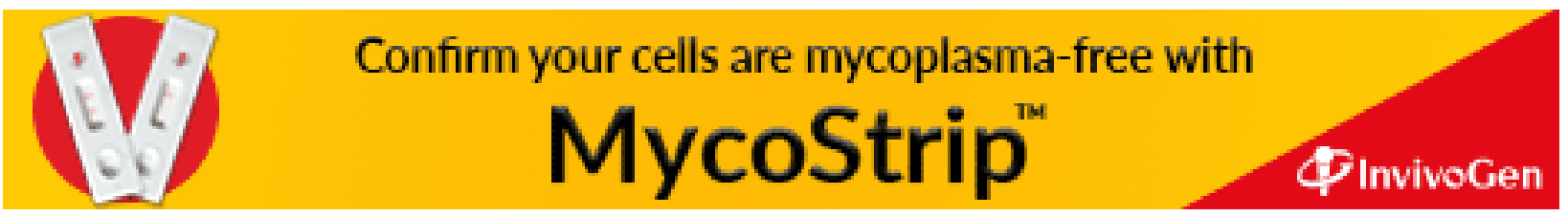

